\title{
The Influence of Cognitive Styles as Promoters of Entrepreneurial Orientation and Intrapreneurship as Drivers of Innovation: The Case of Pharmacy Professionals in Portugal
}

\author{
Sílvia Rebelo ${ }^{1, *(\mathbb{D})}$, Carla Susana Marques ${ }^{2}$ (D) and Gina Santos ${ }^{3}$ (D) \\ 1 Department of Economics Sociology and Management, University of Trás-os-Montes e Alto Douro, \\ 5000 Vila Real, Portugal \\ 2 Department of Economics Sociology and Management, University of Trás-os-Montes e Alto Douro \& \\ CETRAD Research Center, 5000 Vila Real, Portugal; smarques@utad.pt \\ 3 Lusófona University \& CETRAD Research Center, 5000 Vila Real, Portugal; gina.santos@utad.pt \\ * Correspondence: silviamsrebelo@gmail.com
}

check for

updates

Citation: Rebelo, S.; Marques, C.S.;

Santos, G. The Influence of Cognitive

Styles as Promoters of

Entrepreneurial Orientation and

Intrapreneurship as Drivers of

Innovation: The Case of Pharmacy

Professionals in Portugal.

Sustainability 2022, 14, 368. https://

doi.org/10.3390/su14010368

Academic Editor: Víctor Jesús

García-Morales

Received: 7 November 2021

Accepted: 7 December 2021

Published: 30 December 2021

Publisher's Note: MDPI stays neutral with regard to jurisdictional claims in published maps and institutional affiliations.

Copyright: (c) 2021 by the authors. Licensee MDPI, Basel, Switzerland. This article is an open access article distributed under the terms and conditions of the Creative Commons Attribution (CC BY) license (https:// creativecommons.org/licenses/by/ $4.0 /)$.

\begin{abstract}
Innovation in the community pharmacy field has extreme importance in building customer loyalty and competitiveness and, during the COVID-19 pandemic, its value was even more noted. Thus, in this study, we aimed to assess the influence of cognitive styles (rational and intuitive) on individual entrepreneurial orientation and intrapreneurship and how they impact innovation. A questionnaire was applied to 209 community pharmacy professionals in Portugal during the COVID19 pandemic, and PLS-SEM was used to statistically analyze the data obtained. For the results, we perceived those cognitive styles' (rational and intuitive) impact on individual entrepreneurial orientation and partially on intrapreneurship, and this innovation is explained by individual entrepreneurial orientation and intrapreneurship. For the theoretical implications, we have contributed to the advancement of knowledge by establishing and understanding the relationship between the different dimensions suggested and, at the practical level for management, we have perceived where to act at the individual level, to improve innovation and provide suggestions in the directions suggested here. This study is original and innovative because there are no general studies in the literature that have related all the dimensions addressed here, and there is little current research in the community pharmacy field.
\end{abstract}

Keywords: cognitive style; individual entrepreneurial orientation; intrapreneurship; innovation; community pharmacy; COVID-19

\section{Introduction}

In recent years, innovation in community pharmacies has shown to have great importance in building customer loyalty, sophistication concerning the competition, improvement of work processes and profitability, and, in the context of the COVID-19 pandemic phase, in which we found ourselves during this work, has further encouraged the need for innovation.

With this evolution, community pharmacies have moved from being just a place to dispense medications and health products to becoming providers of various services, leading to a growing need for innovation to improve and differentiate the pharmaceutical or information services that are provided to the population [1,2] and also, in a more recent way, the concern with a more sustainable trading system and with a focus on environmental conservation [3].

Pharmacy professionals are both healthcare providers and entrepreneurs [4], so they are responsible for identifying, developing, and providing healthcare services to the population, and skills in innovation and entrepreneurship must be developed for the future improvement of the profession [5]. 
In line with Bogers, Foss and Lyngsie [6], the individual human aspects regarding innovation have rarely been studied, and since innovation depends on the individual characteristics of the workers, this suggests future research is needed, with a greater focus on the individual characteristics of the workers.

Innovation is a process involving several tasks of creation or renovation of procedures [7], processes, products, or services [8] that begins with the generation of the idea, then proceeds with its materialization and dissemination [9]. Being a subject of study in the last 20 years, it is known that innovation is crucial in organizations $[10,11]$ to overcome the competition and meet the needs of customers [12].

The literature has described that the need to foster competitiveness in organizations leads to employees' cognitive approach (cognitive style) as essential to achieving innovation and better results [13-15]. Cognitive style is the way individuals pay attention, perceive problems, and store and make decisions, and is the basis of each individual's behaviour [16-20]; how a collaborator's cognitive style influences idea generation in its fluency and originality relates directly to an individual's innovation potential [21].

It has also been noted that intrapreneurship is essential in the innovation and development of organizations for their improved performance and growth [22]. Intrapreneurship, or employee intrapreneurship (EI) from an individual-level perspective [23], is the exercise of entrepreneurship within an organization [22] and starts from the recognition and exploration of opportunities with the aim of creating new services, products, processes, or businesses [24]. From the perspective of the pharmacy field, an intrapreneur (pharmapreneur) aims to develop new services or improve existing services to meet the unmet needs of the population and is essential in its competitiveness [25].

Additionally, one of the most important contributing factors to entrepreneurship and success is the individual entrepreneurial orientation (IEO) [26], as it is increasingly the individual himself who is the creator of opportunities, leading to a consequent growth of the organization [27]. IEO is a psychological construct that defines the propensity of an individual to behave in an entrepreneurial manner [28], to adapt to new situations, and obtain benefits [29]. Several studies have given importance to the IEO of managers (because it has been seen as a management strategy/vision) and all employees [30].

Following all of the above, the overall aims of this study were to assess how cognitive styles (rational and intuitive) promote IEO and intrapreneurship and how these drive innovations among pharmacy professionals in community pharmacies in Portugal.

Gaps were found in the literature, such as some studies have been conducted under similar dimensions to our study scope, but only in isolation or relating only some of them together, and these studies are practically nonexistent in the field of pharmacy. Although recent studies point to a need for innovation in community pharmacies [4], and it is necessary to find ways for pharmacies to reinvent themselves due to constant changes and the difficult economic phase in which we find ourselves due to the pandemic [31]. No studies aim to explain innovation from an individual perspective with the dimensions that we intend to relate. With this study, we have complemented previous knowledge in each of the dimensions under study and the understanding of the relationships between them and in the pharmacy area.

The method used to conduct the study is the quantitative one because, in our view, we consider it to be the most appropriate for this study as we intend to enlighten the reader on the collection and analysis of data in a clear and objective way, measuring relationships by means of statistical tests. To carry out the research, we developed a questionnaire based on scales validated in previous studies, some used in the health field, and distributed it to 209 community pharmacy professionals in Portugal between 14 April and 3 October 2020, during the COVID-19 pandemic. After collecting the completed questionnaires, we proceeded to verify our hypotheses using structural equation modelling (SEM) and, more specifically, PLS-SEM (Partial Least Squares Structural Equation Modeling). As a result, we see that cognitive styles (rational and intuitive) have an impact on IEO and partially on EI and that IEO and EI explain innovation. Finally, the results are discussed with studies 
within the different dimensions, and the study's conclusions are presented, as well as its implications, limitations, and suggested recommendations for future studies.

This article is structured as follows: this Section 1 aims to introduce and contextualize the theme, and the direction and objectives of the article are presented. The Section 2 presents the theoretical evaluation carried out on cognitive styles, IEO, EI and innovation, explaining the research hypotheses and ending with the exposure of the conceptual research model. Section 3 explains the entire methodology, from the methods to the tool used and the characterization of the sample. Section 4 presents the results obtained, and Section 5 discusses these results. The Section 6 presents the conclusions and the limitations and proposes future lines of research.

\section{Theoretical Framework}

\subsection{Cognitive Styles: Rational and Intuitive}

Cognition is the way humans acquire, store, and use knowledge $[32,33]$ and results from the interaction between each human being's unique biological constitution (mindbrain - and body) with society/environment and aims to produce future actions [34]. This individual-environment interaction is constantly changing, limiting and differentiating the way information is processed [34,35].

Cognitive style, cognitive control or cognitive strategies are the names commonly given to the means of conscious and unconscious information processing [33,36-38]. It is considered by psychologists to be an individual behavioural factor with importance in management [39] and in how individuals generate ideas and implement them, and there is increasing interest in its study in this area [14].

Witkin and Goodenough [40] pioneered the study of psychological differentiation and divided cognitive style into field dependence and field independence. Fowler [41], on the other hand, presents two distinct forms of information processing: analytic style and integrative style and in the course of researching cognitive styles over the years, many models have been studied [42,43].

In this study, we focus only on the most widely used theory: the dual-process theory or dichotomy of human thinking [16], in which cognitive styles are divided and designated as rational and intuitive. In short, the dual-process theory describes the existence of a neural division between the reflexive and reflective or analysis-intuition process and is a widely used theoretical tool in the study of cognition [44,45]. Based on the theories presented, the characteristics of analytical cognitive style can be summarized as longer processing, a sequential unwinding, an active conscience, reason oriented, analysis and logical connections, performs evaluation of alternatives and is based on new situations and causal relationships [46]. On the other hand, the intuitive cognitive style has a more accelerated processing, a holistic unwinding, without conscience and passive, has the feeling of certitude and trust, acts with complex much information and it's based in experience [46].

According to some authors, the intuitive cognitive style is predominant in entrepreneurs, being referred to as just intuition [38,47], and this is important in identifying opportunities and making decisions [48] due to the characteristics of the organizational environment (incomplete information, uncertainty, time, etc.) [13]. However, according to Armstrong et al. [39] entrepreneurs may not necessarily have an intuitive cognitive style because a multidimensional approach has advantages at different stages of entrepreneurship and Castellano, Maalaoui, Safraou and Reymond [49] found in their study that both cognitive styles are essential at different stages of entrepreneurship and according to other authors, the organization wins if the team has a versatility of cognitive styles [50,51].

Entrepreneurial behaviour is influenced by cognitive style because it moderates the relationship of entrepreneurial behaviour with optimism and persistence [52]. There is also a positive relationship between cognitive styles and innovative behaviour, as concluded by Visser and Faems [53] in their study where they wanted to determine if CEOs' cognitive styles influence explorative and exploitative innovation in the companies they led or 
by Naseer, Khawaja, Qazi, Syed and Shamim [54] in their study where they found that creative cognitive style moderates the relationship between information proactivity and open innovation, which is higher when employees are high in creative cognitive style.

Cognitive styles are also considered an individual behavioural factor with importance in management [39], decision making [45,55,56], opportunity-seeking [46], how individuals generate ideas and implement them [14] and in improving organizational performance [57], so their study is relevant to the community pharmacy subject.

\subsection{Individual Entrepreneurial Orientation}

Entrepreneurial orientation (EO) is a strategic positioning of entrepreneurship undertaken by an organization and encompasses decision-making practices, management philosophies and strategic behaviours [58] to identify and exploit untapped market opportunities [59] and is vital to organizational performance [60].

While entrepreneurship is the force that drives promising organizations (content: what?), EO is an essential component of the organization's strategy that aims to decide and drive efforts toward a goal (the process: how?) [61,62] and can be a reason for competitive advantage and strategic renewal [63]. This ambitious effort towards entrepreneurship includes different processes: experimenting with new technologies, taking advantage of new opportunities that arise in the market, and undertaking risk-taking [63]. EO is vital in organizations as it allows them to cope with the continuous changes and pressures of the market and the tendency for internal inflexibility and inertia in organizations [30].

The concept of EO was first explored by Mintzberg [64], and this construct usually features between three to five identified behaviours that we are going to describe. Miller [65] developed a scale to assess EO based on three variables present in an organization's behaviour: innovation, risk, and proactivity. However, it was after the publication of the EO scale of Covin and Slevin [66], using the exact three dimensions, that empirical research on EO at an organizational level of analysis was affirmed [67], and Lumpkin and Dess [63] added two more EO dimensions to be considered: autonomy and competitive aggressiveness. Innovation relates to creativity and experimentation in new products, services, technology and processes; risk relates to bold decisions, adventure into the unknown and use of high resources in uncertain environments; proactivity suggests prospection and searches for opportunities and anticipation of products and services in relation to the competition; autonomy is designated by the creation of independent actions directed to create something new and achieve it; competitive aggressiveness is characterized by an offensive, aggressive and competitive posture of the intensity of an organization's effort to overcome rivals [68]. Still, the first three remain the most widely used [69].

EO can easily be adapted to the individual level because many organizations are small or medium-sized and with a single owner or manager, and usually, the decision and planning are made by a single person - the individual entrepreneur [27], resulting in EO from the behaviour of an individual-the IEO [69]. Although few studies assessed IEO [26], it is a multidimensional approach and encompasses the exact dimensions as EO [70]. Santos, Marques and Ferreira [71] also include passion and perseverance. Entrepreneurial passion (in entrepreneurs) is understood as the emergence of positive and intense feelings when engaging in organizational activities associated with their identity [72], such as business, teams and their entrepreneurial skills within the organization [73]. Perseverance involves setting ongoing goals and putting in the necessary effort over time to achieve them despite adversity $[73,74]$.

The study of its antecedents has been scarce [75], however, it is perceived that IEO also has a cognitive approach which tries to understand the aspects of cognition that are important in the entrepreneurial process, so it makes sense to associate cognitive differences with the way strategy is seen by entrepreneurs $[29,75]$. Within the few studies found, a recent work by Zollo et al. [29] shows the conduct of a study in small and medium European organizations where they concluded that cognitive styles are mediators in the causal relationship between entrepreneurial passion, IEO and strategic entrepreneurship behaviour. 
Considering the above, we present the following research hypotheses:

Hypothesis 1 (H1). The rational cognitive style influences individual entrepreneurial orientation.

Hypothesis 2 (H2). Intuitive cognitive style influences individual entrepreneurial orientation.

\subsection{Intrapreneurship}

EI is a subtype of entrepreneurship that has become important [76] and whose study has increased over the last two decades [24]. It is defined as a strategic working behaviour to create new ventures and strategic renewal [23] by the occurrence of initiative and risktaking by employees of an organization [77].

Most studies conducted in this area aim to assess how it occurs on the organizational and corporate sides [22] and its benefits to the organization [78] rather than individual employees' intrapreneurial performance [76,79]. However, this has been shown to be of great importance because from passive employee behaviour, proactive and innovative behaviour is now noticed as an endeavour to develop small changes in the organization $[24,80]$ and organizations increasingly rely on the entrepreneurial role of their employees [23].

The intrapreneur in his organization seeks new business and new activities, services, products, strategies, and technologies [81]. Thus, organizations increasingly rely on their employees' entrepreneurial role to improve and grow in their procedures and competitiveness [23], because these should, first of all, benefit the organization and only then the employee himself [24]. Gawke et al. [79] found that at the individual level, intrapreneurship, personal resources (optimism, resilience, self-efficacy) and commitment to work have a causal and cyclical relationship. Thus, if one of them is increased, the others also increase and can be factors to be worked on in organizations.

This importance is also denoted in the emergence of a theory that explains the relationship between work experiences and EI: the JD-R (job demands-resources) theory. In a simple way, this theory states that employers have expectations (job demands), and employees invest their physical, emotional and cognitive resources to achieve them [82]. If employees' labour and personal resources are sufficient, employees become more engaged at work. On the contrary, employees feel exhausted and stressed if they are insufficient. If individuals are intrapreneurial, they improve their people resources and, consequently, work engagement [79].

EI is a complex construct that results from distinct factors, but in this study we will focus only on individual and behavioural factors.

Allinson et al. [13] were the first to study the relationship of cognitive style with entrepreneurial intention because they are essential in explaining entrepreneurial behaviour [46]. And if it is on individual behaviour that an organization's activity and entrepreneurship depend, studying the relationship of IEO as a primary antecedent of EI is vital [5,60]. Kraus et al. [60] found that an employees' IEO is directly related to EI, and, in a study conducted by Razavi and Aziz [83], it was also found that there is a significant effect of IEO dimensions on intrapreneurial intention.

According to the above, the following hypotheses are listed:

Hypothesis 3 (H3). Rational cognitive style influences intrapreneurship.

Hypothesis 4 (H4). Intuitive cognitive style influences intrapreneurship.

Hypothesis 5 (H5). Individual entrepreneurial orientation influences intrapreneurship.

\subsection{Innovation}

Innovation is related to the concept of novelty, and the innovative activity may be in new products, new services, new methods, new markets, new sources, new forms of organization [84], improvements of existing products or services [85] or improvements of 
the work environment and tasks $[9,86]$ in order to have a significant impact on competitive advantage and performance in small and organizational performance [10].

Already Drucker [87] highlighted the importance of innovation in his book The Practice of Management and the value of its study at the organizational level [8], as he considers it essential for value creation in small organizations [88] such as pharmacies and in social and economic development [83].

The literature around innovation can be divided into different perspectives: organizational innovation can be seen from the behavioural perspective (adoption of innovation by the organization) or as a willingness to change [8], and the innovative behaviour of an individual relates to the generation or adoption of ideas and the effort to implement and carry out procedures [89,90], to achieve new levels of improvement [9].

Pharmacies have been encountering difficulties due to the complex health environment and the demands regarding medicines [91] and, similar to other organizations, they have a dual approach: the need to provide a quality service (public interest of the right to health) and a competitive environment (entrepreneurial nature of professionals) [4]. In this sense, it is verified that in pharmacies, the diffusion of knowledge (tacit and explicit) facilitates innovation processes and improves performance [92] and that teamwork and knowledge sharing among everyone are essential to creating value and innovative practices, being essential that the leader in the pharmacy field involves its employees in order to obtain the best results for the pharmacy, the user and the team [91].

Innovation in the pharmacy field can bring advantages such as improved customer relationships and improved working capacity due to improved relationships with other healthcare professionals and other pharmacies [93].

Several authors denote the existence of a relationship between EO and innovation. For example, Genc et al. [12] in their study conducted in small and medium-sized organizations, found that EO positively relates to innovation and mediates its relationship with internationalization. Liu and Lee [94] concluded that EO and the innovation climate in an organization is positively related to service innovation. Alegre and Chiva [95], in their study in Italian and Spanish tile producing industries, found that there is a significant positive relationship between EO as an antecedent of innovation performance. Widya-Hasuti, Mardani, Streimikiene, Sharifara and Cavallaro [96], in their study, realized that EI is one of the internal organizational strategies for achieving sustainable innovation mediated by process innovation in small and medium-sized enterprises.

Intrapreneurship is also seen as a factor that can improve innovation in organizations $[97,98]$.

According to the above, the following research hypotheses are formulated:

Hypothesis 6 (H6). Individual entrepreneurial orientation promotes innovation.

Hypothesis 7 (H7). Intrapreneurship promotes innovation.

\subsection{Research Model}

According to the exposed theoretical framework and the different findings of several researchers, we propose the conceptual research model illustrated in Figure 1. 


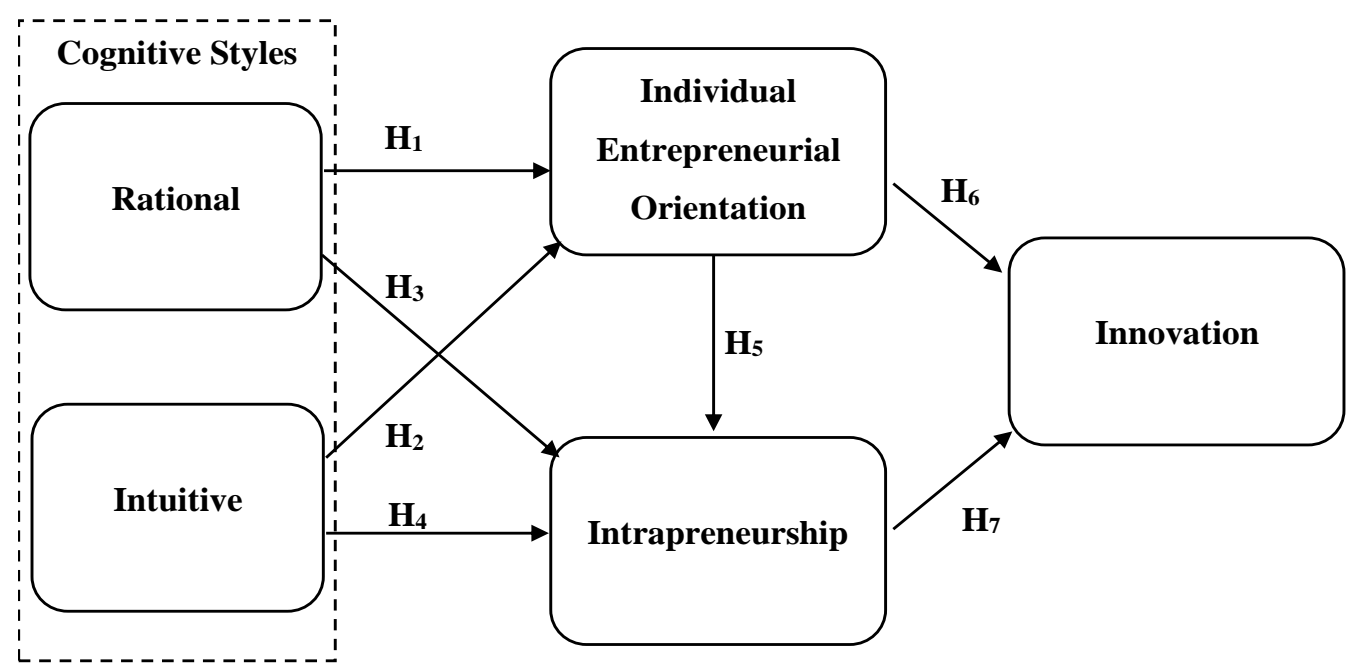

Figure 1. Conceptual research model.

The scales used to study each dimension were the following:

1. Cognitive Styles: The Cognitive Style Index by Allinson and Hayes [16] was used, consisting of 10 items to assess the rational cognitive style and 10 items to assess the intuitive cognitive style;

2. IEO: The Individual Entrepreneurial Orientation scale of Santos et al. [71] was used, consisting of 3 items to assess Risk, 4 items to assess Innovation, 3 items to assess Proactivity, 4 items for Passion and 5 items for Perseverance;

3. EI: The Employee Intrapreneurship Scale (EIS) by Gawke et al. [23] composed of 10 items was used;

4. Innovation: The Innovative Behaviour (4 items) and Openness to Innovation (6 items) dimensions from the work of Carlucci, Mura and Schiuma [99] were used, as well as the Innovation Outputs ( 3 items) from the Innovative Behaviour Inventory (IBI) by Lukes and Stephan [90].

\section{Materials and Methods}

Data collection consisted of the completion of a questionnaire by professionals working in the community pharmacy (pharmacists, pharmacy technicians and others) in Portugal between April and October 2020, immediately after the beginning of the pandemic. Initially, a pre-test was carried out and, once its practical operability and effectiveness were verified, data collection proceeded. The questionnaire was distributed in two ways: face-to-face paper delivery in a closer geographical area and telephone contact/email to pharmacies throughout the country to disclose a google docs link to access it. Statistical analysis was performed by structural equation modelling (SEM) and, more specifically, PLS-SEM (Partial Least Squares Structural Equation Modeling).

The questionnaire consisted of 74 questions, divided into 5 sections. The first section aimed to collect sociodemographic data. The following four sections aimed at the assessment of the dimensions under study according to the mentioned scales, consisting of a seven-point Likert scale, where the score " 1 " corresponds to the value "strongly disagree" and the score "7" corresponds to the value "strongly agree".

Common method bias is a potential concern [100] when collecting behavioural and attitudinal data from self-report questionnaires at a particular point [101], so special care was taken to lessen its impact and gauge its existence. Thus, to reduce this bias, this study sought to ensure that all participants understood the confidentiality of the questionnaire and the questions contained therein, whether in the case of a face-to-face delivery on paper or in the case of a telephone or email contact. These aspects were emphasized, with respondents motivated to answer correctly and accurately. Podsakoff et al. [100] suggested that ensuring anonymity on the part of the respondent may lead them to be less likely to 
edit their responses and have less apprehension of evaluation. To ascertain collinearity, the proposal of Kock and Lynn [102] was adopted by performing the collinearity test. Through this procedure, the variance inflation factors (VIFs) for all model latent variables were evaluated. The occurrence of a VIF more significant than 3.3 is proposed as an indication of collinearity and also as an indication that a model may be contaminated by common method bias. Therefore, if all VIFs resulting from a total collinearity test are equal to or less than 3.3, the model can be considered free of common method bias.

Of the 215 questionnaires obtained, only 209 were valid, so the sample is 209 professionals. Of the respondents, $72.7 \%$ (152) are women, there is a predominance of the age group below 30 years $(72 ; 34.4 \%)$, and academically most have a Bachelor's degree (94; $45 \%$ ). In the professional category, $55.1 \%$ (115) are pharmacists and $41.1 \%$ (86) are pharmacy technicians, with the remaining having another professional category.

\section{Results}

PLS-SEM has a set of general guidelines (practical rules) that serve as guidelines for evaluating the model results and interpreting the results [103-106]. Thus, according to the guidelines, as the proposed model is a 2nd order hierarchical model, the 2-step approach was used [107-109], which consists in the psychometric evaluation of the 2nd order latent variables (IEO and innovation), proceeding to determine the scores of the lower order factors according to the following order.

(1) Factor validity (>0.7) [110] was verified for all items except for the indicator AI4 (Meeting the customers' /users' requests) of the "Openness to Innovation" dimension of the Innovation construct $(\lambda=0.66)$, which was maintained. (2) Internal consistency reliability was ensured for the two constructs under analysis with composite reliability values-CR $(\geq 0.88)$ [111], as well as very good $\rho \mathrm{A}(\geq 0.81)$ [112] and Cronbach's $\alpha(\geq 0.80)$. (3) Convergent validity was ensured by the average variance extracted (AVE) values $(>0.60)$. (4) To assess discriminant validity, one of the criteria used was the Fornell and Larcker [113]. However, Henseler, Ringle and Sarstedt [114] show that the Fornell-Larcker criterion does not perform well, particularly when the factor loadings of the indicator in a construct differ only slightly (for example, all the factor loadings of the indicator oscillate between 0.65 and 0.85 ) and instead, Henseler et al. [114] proposed the HeteroTrait-MonoTrait (HTMT) ratio of correlations [115] which is the one represented in this study to gauge discriminant validity. Discriminant validity is verified because HTMT is $<0.90$ [114]. The scores of the subconstructs mentioned above were used as indicators in the proposed model.

\subsection{Measurement Model (Outer Model)}

The evaluation of the measurement model followed the same steps of the previous section considering all constructs included in the final model. In the first instance, the factor loadings of the indicators of the various latent variables were analysed. It was found that all the factor loadings presented values greater than 0.7 with the exception of two (R2 (I perform tasks systematically) of the Rational Style $(\lambda=0.697)$ and I7 (I use my heart as a guide for action) of the Intuitive Style $(\lambda=0.650))$. It was decided to keep them in the model.

As shown in Table 1, the reliability of the internal consistency (CR) under analysis was ensured with the $C R$ values all being greater than $0.70(\geq 0.87)$, as well as those of $\rho \mathrm{A}(\geq 0.82)$ and Cronbach's $\alpha(\geq 0.82)$ was very good. The values of the mean extracted variance (VEM) proved to be higher than 0.64 , thus falling within the recommended interval $(>0.50)$, and convergent validity was ensured [116]. Table 2 shows that all correlations' values of the HTMT ratio are well below the threshold value of 0.90 and the more conservative value of 0.85 , thus ensuring discriminant validity. 
Table 1. Constructs of the measurement model reliability of internal consistency and convergent validity.

\begin{tabular}{lllll}
\hline Latent Variables and Respective Dimensions & $\mathbf{C R}$ & $\boldsymbol{\rho}_{\mathbf{A}}$ & $\alpha$ Cronbach & VEM \\
\hline Cognitive styles: Rational style & 0.96 & 0.96 & 0.95 & 0.70 \\
Cognitive styles: Intuitive style & 0.95 & 0.95 & 0.94 & 0.64 \\
IEO & 0.87 & 0.82 & 0.82 & 0.58 \\
Intrapreneurship & 0.96 & 0.96 & 0.96 & 0.73 \\
Innovation & 0.94 & 0.90 & 0.90 & 0.83 \\
\hline
\end{tabular}

Table 2. Analysis of the HTMT ratio in the final measurement model.

\begin{tabular}{|c|c|c|c|c|c|}
\hline & (1) & (2) & (3) & (4) & (5) \\
\hline (1) Cognitive Styles: Rational style & & & & & \\
\hline (2) Cognitive style: Intuitive style & 0.54 & & & & \\
\hline (3) IEO & 0.57 & 0.54 & & & \\
\hline (4) Intrapreneurship & 0.34 & 0.25 & 0.67 & & \\
\hline (5) Innovation & 0.60 & 0.42 & 0.84 & 0.81 & \\
\hline
\end{tabular}

\subsection{Structural Model}

The criteria for assessing the structural model and its predictive ability include the coefficient of determination $\mathrm{R}^{2}$ of the endogenous latent variables [103] and the effect size $\mathrm{f}^{2}$ [117]. As a guide, $\mathrm{R}^{2}$ values of $0.75 ; 0.50$ and 0.25 can be considered substantial, moderate and weak, respectively [106,118]. Effect size $\left(\mathrm{f}^{2}\right)$ complements $\mathrm{R}^{2}$, and Cohen [117] suggests $\mathrm{f}^{2}$ values of $0.02 ; 0.15$, and 0.35 for the predictive variables' small, medium and large effects. Another way to gauge the predictive relevance of the model is by calculating the Stone-Geisser $\mathrm{Q}^{2}$ value $[119,120]$ and $\mathrm{Q}^{2}$ values greater than $0 ; 0.25$ and 0.50 represent a small, medium and large predictive relevance of the PLS structural model.

Figure 2 shows the SmartPLS output with the values of the regression coefficients $(\beta)$ in the paths between the different constructs of the model, as well as the $\mathrm{R}^{2}$ values and the factor loadings of the latent variables, and Table 3 shows the size of the effects of predictor variables on endogenous variables $\left(\mathrm{f}^{2}\right)$ and the coefficient of determination values $\left(\mathrm{R}^{2}\right)$.

Table 3. Size of the effects of predictor variables on endogenous variables.

\begin{tabular}{lccc}
\hline Paths & $\mathbf{R}^{\mathbf{2}}$ & $\mathbf{f}^{\mathbf{2}}$ & $\mathbf{f}^{\mathbf{2}}$ Effect \\
\hline Rational Style $\rightarrow$ IEO & 0.34 & 0.16 & Medium \\
Intuitive Style $\rightarrow$ IEO & 0.34 & 0.08 & Small \\
Rational Style $\rightarrow$ EI & 0.37 & 0.00 & - \\
Intuitive Style $\rightarrow$ EI & 0.37 & 0.01 & - \\
IEO $\rightarrow$ EI & 0.37 & 0.40 & Large \\
IEO $\rightarrow$ Innovation & 0.70 & 0.41 & Large \\
EI $\rightarrow$ Innovation & 0.70 & 0.51 & Large \\
\hline
\end{tabular}

In the estimation of model factors, the VIF was evaluated in the collinearity diagnosis for values higher than the recommended threshold of 3.3 [121]. The results indicated that all values are less than $3.3\left(\mathrm{VIF}_{\mathrm{IEO}}=1.403 ; \mathrm{VIF}_{\mathrm{EI}}=1.627 ; \mathrm{VIF}_{\text {Innov }}=1.578\right)$, which does not indicate any common method bias. Therefore, it can be inferred that common method bias did not influence the participants' responses. 


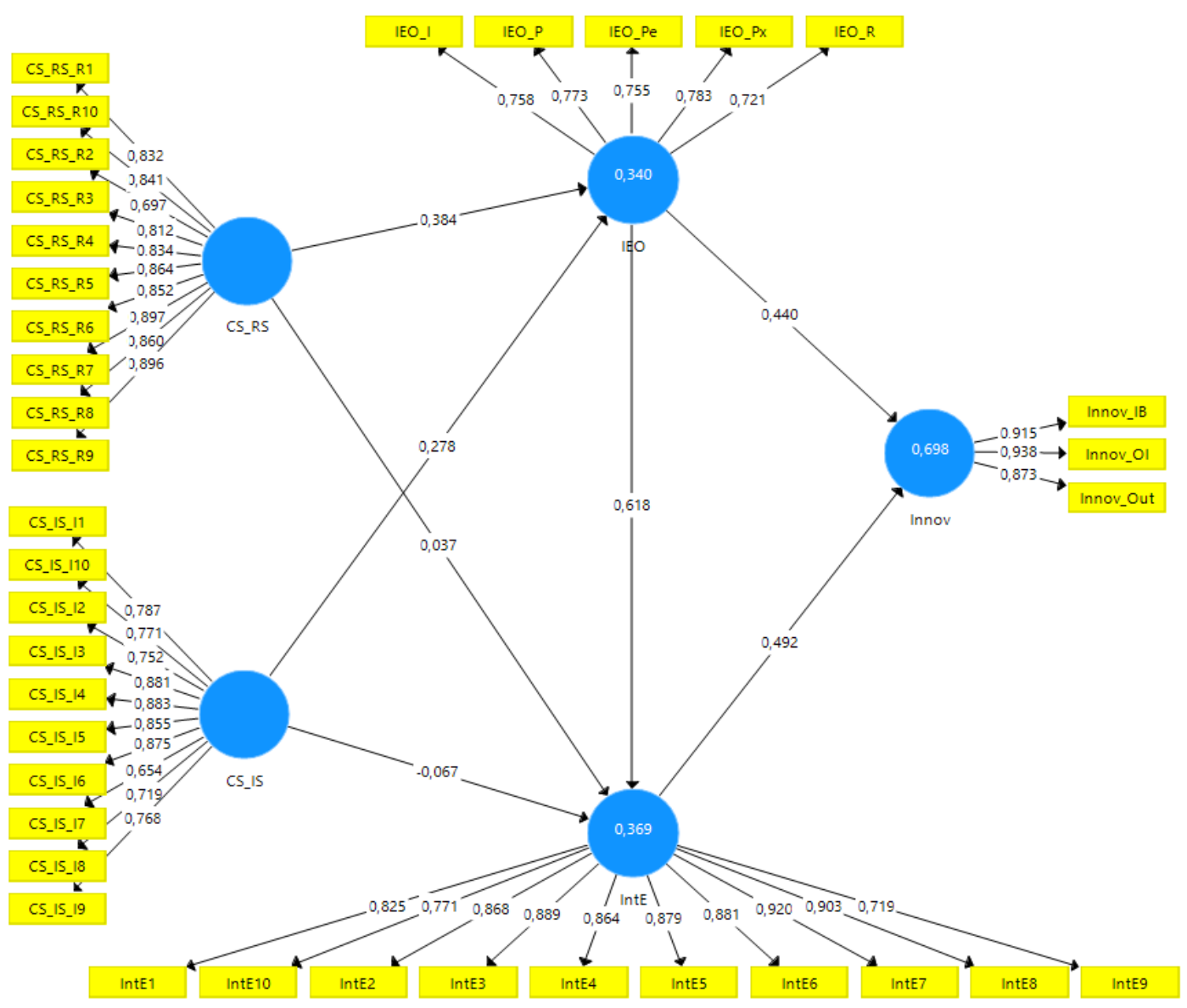

Figure 2. SmartPLS' output with the indication of the determination coefficients $R^{2}$ and values of the regression coefficients $(\beta)$ (inner model) and the factor loadings $(\lambda)$ of the indicators of each latent variable (outer model).

\subsection{Hypotheses Testing}

After proving the explanatory and predictive power of the model, the final step was to evaluate the statistical significance and relevance of the regression coefficients. The bootstrap routines were executed to evaluate the significance of the regression coefficients. In this way, it was possible to analyze, besides the direct effects, the indirect effects of a construct on another construct through one or more intervening constructs. This type of effect is particularly relevant in evaluating mediation effects [122].

In Figure 3 we illustrate the structural model with the regression coefficients and statistical significance, and for a more detailed analysis, we present Table 4.

Table 4. Hypothesis results.

\begin{tabular}{lcccccr}
\hline \multicolumn{1}{c}{ Direct Effect } & $\boldsymbol{\beta}$ & $\boldsymbol{p}$ & $\begin{array}{c}\text { Is Hypothesis } \\
\text { Supported? }\end{array}$ & Mediated Effect & $\boldsymbol{\beta}$ & \\
\hline H1: Rational Style $\rightarrow$ IEO & 0.384 & $<0.001$ & Yes & & \\
H2: Intuitive Style $\rightarrow$ IEO & 0.278 & $<0.001$ & Yes & Rational Style $\rightarrow$ IEO $\rightarrow$ EI & 0.238 & $<0.001$ \\
H3: Rational Style $\rightarrow$ EI & 0.037 & 0.618 & Partially & R & $<0.172$ \\
H4: Intuitive Style $\rightarrow$ EI & -0.067 & 0.365 & Partially & Intuitive Style $\rightarrow$ IEO $\rightarrow$ EI & $<01$ \\
H5: IEO $\rightarrow$ EI & 0.618 & $<0.001$ & Yes & IEO $\rightarrow$ EI $\rightarrow$ Innovation & 0.304 \\
H6: IEO $\rightarrow$ Innovation & 0.440 & $<0.001$ & Yes & & $<0.001$ \\
H7: EI $\rightarrow$ Innovation & 0.492 & $<0.001$ & Yes & & \\
\hline
\end{tabular}




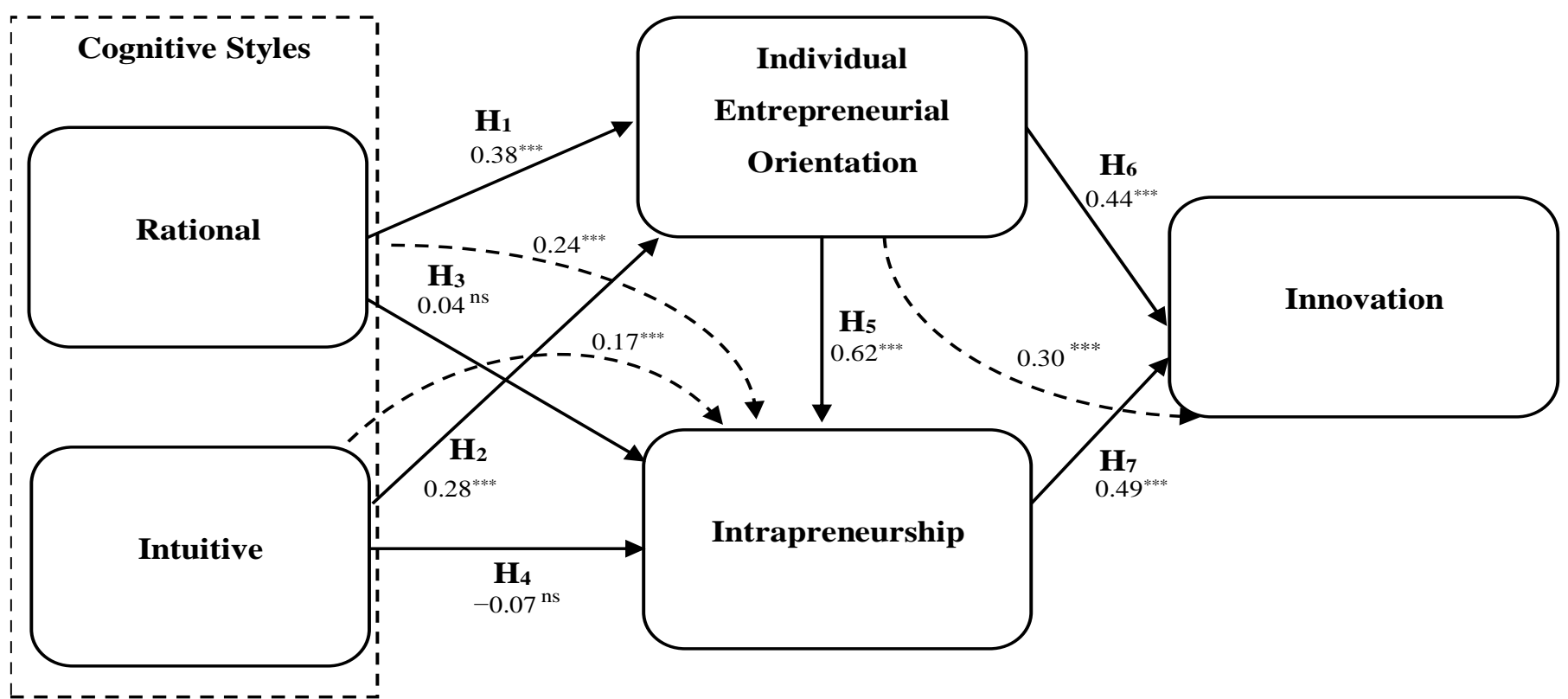

Figure 3. Structural model (regression coefficients and statistical significance). Note: ${ }^{* *} p \leq 0.001$; $p>0.01{ }^{\text {ns }}$ not supported.

It is perceived that both the rational cognitive style $\left(\beta_{\text {IEO }} \cdot \mathrm{RS}=0.384 ; p<0.001\right)$ and the intuitive cognitive style ( $\beta_{\text {IEO }}$ IS $\left.=0.278 ; p<0.001\right)$ positively impact the IEO supporting $\mathrm{H} 1$ and $\mathrm{H} 2$ and that it is the rational cognitive style that influences the IEO the most $\left(\beta_{\text {IEO } \cdot R S}=0.378>\beta_{\text {IEO IS }}=0.278\right)$. On the other hand, both the rational cognitive style $\left(\beta_{\mathrm{EI} \cdot \mathrm{RS}}=0.037 ; p=0.618\right)$ and the intuitive cognitive style $\left(\beta_{\mathrm{EI} \cdot \mathrm{IS}}=-0.067 ; p=0.365\right)$ revealed no direct relationship with EI. However, it was possible to perceive a mediating effect of IEO between both cognitive styles ( $\beta_{\mathrm{EI} \cdot \mathrm{RS} \text { I IEO }}=0.238$ and $p<0.001 ; \beta_{\mathrm{EI} \cdot \mathrm{IS} \mid \mathrm{IEO}}=0.172$ and $p<0.001$ ) and EI so we can say that hypotheses $\mathrm{H} 3$ and $\mathrm{H} 4$ are partially supported, i.e., despite not being supported when we consider the direct effects, these are supported when the Cognitive Styles are mediated by IEO. With regard to H5, it is found that IEO impacts on EI $\left(\beta_{\mathrm{EI} \cdot \mathrm{EIO}}=0.618 ; p<0.001\right)$ supporting the hypothesis. Finally, both IEO $\left(\beta_{\text {Innov } \cdot \text { IEO }}=0.440 ; p<0.001\right)$ and EI $\left(\beta_{\text {Innov } \cdot E I}=0.492 ; p<0.001\right)$ impact on innovation, so that $\mathrm{H} 6$ and $\mathrm{H7}$ are supported, verifying a considerable effect of IEO on Innovation mediated by EI ( $\beta_{\text {Innov }} \cdot$ IEOIEI $\left.=0.304 ; p<0.001\right)$. It is concluded that innovation in community pharmacies in Portugal is explained by IEO and EI.

We adopted the procedures recommended by Zhao, Lynch and Chen [123] concerning mediation effects, which consist of two steps. In the first step, the significance of indirect effects is determined, and, in the second step, the type of effects or mediation is determined. Whenever we find a statistically significant indirect effect in the first step, we are dealing with a mediation effect, which happens in the proposed model since the three indirect effects reported are significant. In the second step, if the direct effect is not significant, we are faced with a case of complete mediation, which happens in the Rational Cognitive Style path for the EI construct and in the Intuitive Cognitive Style path for the EI construct. In other words, these full mediations mean that the effect of the cognitive styles variables on $\mathrm{EI}$, are completely transmitted with the help of the IEO variable. In the case of a significant direct effect, we face a case of partial mediation, which happens on the path from the IEO to Innov, which is called a complementary mediated effect, because the regression coefficients of the direct and indirect effect have the same sign. In this type of mediation, it makes sense to assess its strength, i.e., calculate the ratio of the indirect-to-total effect. This ratio is known as the variance accounted for (VAF) value. VAF determine the extent to which the mediation process explains the dependent variable's variance. The rule of thumb is if the VAF is less than $20 \%$, one should conclude that nearly zero mediation occurs; a situation 
in which the VAF is larger than $20 \%$ and less than $80 \%$ could be characterized as a typical partial mediation [105], and a VAF above $80 \%$ indicates a full mediation. In the case of the path from the IEO to Innov construct, we found that VAF $=0.304 /(0.440+0.304)=40.86 \%$, so this is a typical partial mediation.

\section{Discussion}

In this study, a model for explaining innovation was formulated and tested considering the influence of cognitive styles (rational and intuitive) on IEO and EI and their impact on innovation.

The results show good support for most of the predicted relationships. As an assumption, we realize that our $\mathrm{H} 1$ and $\mathrm{H} 2$ are supported. These results are in line with hypotheses proposed in the literature, where it is theorized that cognitive styles have differences in information processing and decision-making and thus could explain IEO [29,75]. However, during our research, the literature found that relates the two dimensions were scarce and, in a study conducted by Cools and Broeck [75], it was found that cognitive styles were not shown to be of significant contribution in explaining EO when compared to other individual traits (ambiguity tolerance, self-efficacy, proactive personality, locus of control, and need for achievement).

Our H3 and H4 were partially supported due to finding IEO's mediating effect between cognitive styles and intrapreneurship. However, the literature shows a positive relationship between cognitive styles and entrepreneurship [13,38,47,49,52,124,125]. The mediation found makes sense, as IEO is defined as the propensity of an individual to behave in an entrepreneurial way [28], and EI is the exercise of entrepreneurship within an organization [22] and is a multidimensional concept that can lead to improvements in the organization at different levels, so it can be used as a tool of the organization to achieve the desired impact according to its orientation and vision at each moment [97]. Still, according to Ferreira and Coelho [10], EO creates a stimulus, culture and strength to reinforce the effects of other hypotheses. We also found that rational cognitive style has a higher relationship with EI than intuitive cognitive style $\left(\beta_{\mathrm{ER} \cdot \mathrm{EI}}=0.037\right.$; and $\left.\beta_{\mathrm{EI} \cdot \mathrm{EI}}=-0.067\right)$, which is not in line with the literature that states this relationship is higher with intuitive cognitive style $[38,47,48,124]$, but several authors also argue for a multidimensional approach where there should be cognitive flexibility between both styles $[19,39,49,125,126]$ because both are important at different stages of entrepreneurship, as well as the importance of style diversity in a team for improved creativity [50].

$\mathrm{H} 5$ is also supported and is an expected relationship as employees with a high IEO tend to develop intrapreneurship $[60,83,127]$. This relationship can be explained because in an organization the owner or manager fosters behaviour in his organization, creating an entrepreneurial environment and culture, then it is expected that employees will follow their behaviour through IEO and exhibit intrapreneurship because ultimately it is the behaviours of individuals that organizations depend on in the search for innovation, new opportunities and solutions $[10,60]$. Furthermore, the IEO dimensions (risk propensity, innovativeness, proactivity, perseverance, and passion) are characteristics that lead to intrapreneurial behaviours $[30,69,83,128]$.

$\mathrm{H} 6$ is also true, and this result is supported by numerous pieces of literature in the field of entrepreneurship [12,78,94-96,129], so IEO can be considered a practice that leads organizations to create innovation [68]. Furthermore, entrepreneurial performance in small organizations such as pharmacies is innovative, risk-taking and proactive (dimensions of IEO) [130], and as they are smaller organizations, they are more flexible and can more easily use EO to improve performance [68].

H7 is also accurate and agrees with the literature $[97,98]$ because EI is the practice of entrepreneurship within the organization itself and is a strategy for developing efforts in innovation, revitalizing the business, adapting to changes, improving its performance [131] and seeking new strategies, being important especially in small and medium-sized organi- 
zations [132] such as pharmacies. In addition, intrapreneurship and innovation $[97,98]$ are considered powerful strategies in developing organizations' processes [133].

A mediating effect of EI between IEO and Innovation was also found, which makes sense because innovation occurs when after internal and external analyses are carried out, an idea is generated that creates an advantage for the organization concerning its competitors for some time [10], making us realize that the IEO leads to EI and this leads to the occurrence of Innovation.

The pandemic probably influenced the results obtained. It may have affected the way professionals were using their cognitive style and their IEO and EI. At this work, no studies of these topics were found during COVID-19. According to the literature, the only dimension that was certainly positively influenced was an innovation. However, we noticed that the $R^{2}$ value of innovation is moderate $\left(R^{2}=0.698\right)$, which leads us to believe that other factors not described contributed to the innovation of community pharmacy professionals.

\section{Conclusions}

Innovation in pharmacies can bring improvements in different sectors, such as customer service, quality of work and processes, and the differentiation of the supply of services. Thus, we tried to understand which individual characteristics could encourage innovation and how this relationship occurs.

To carry out this study, an explanatory model of innovation was proposed, and it was concluded that the cognitive styles (rational and intuitive) of the professionals impact on the IEO and that this mediates the relationship between the cognitive styles (rational and intuitive) and EI. Intrapreneurship also has a mediating effect between IEO and innovation. The results obtained are of extreme importance for the knowledge of academics and professionals.

At the practical level, it suggests guiding professionals to tasks that stimulate the intuitive cognitive style because in the literature it is significantly related to intrapreneurship. It is also essential to encourage the practice of entrepreneurship by developing the motivational factors of each employee, as well as the creation by the managers of a favourable environment in the pharmacy, perhaps by providing training in areas related to innovation and entrepreneurship, encouraging and stimulating their learning, creativity and search for opportunities. The adequacy of remuneration or other compensation would also be an essential factor, as creating intrapreneurship and innovation in the organization would add value only to the organization and not to the employee, which can be demotivating. The stimulus for an IEO and EI should be created early on in academic training, familiarizing students with the concepts and procedures and developing their entrepreneurial spirit.

Innovation in community pharmacies occurs mainly in the services provided, and if both the previous characteristics are encouraged, the occurrence of innovation has a greater chance of happening. It could be interesting to hold monthly meetings to understand the evolution of the ideas already implemented and discuss innovative ideas to be developed in the future. However, the reality of each pharmacy is individual, as there are managers who have an EO and not only carry out but also allow the EI of the employees and there are managers who are more closed, without an EO and do not allow suggestions for improvement. It would be interesting if the community pharmacy managers were aware of this study and understood the real potential of their teams.

Also, from a management perspective, we believe that the results of our study can be presented to the management of community pharmacies so that they can make their conclusions and adaptations to innovate in a more effective, profitable and sustainable way.

The limitations found began with a short bibliography on the theme of the four dimensions studied in community pharmacy professionals, followed by the pandemic phase in which the questionnaire for data collection was distributed, which generated difficulty in filling it out due to work overload or teams working mismatched, and there may be a possible bias in the results for the same reason because the creation of innovation during the pandemic was a mandatory reality. Furthermore, the questionnaire itself as 
a data collection method has limitations. The sample is not representative of all regions of the country and the fact that only one profession was assessed (homogenization of the sample) is also a limitation of this work.

Given the low level of research on these themes, not only in the pharmacy field, but also in a general context, we hope to have created curiosity and incentive for other researchers to carry out future studies since we were able to show the potential of the themes under study. As a suggestion for possible lines of research, we propose the approach of other perspectives of managers or technical directors through the application of interviews; the application of the questionnaire in a larger sample and even making a comparison of the results between rural areas, cities and islands; repeating the study in a non-COVID-19 phase to verify whether the results would be the same; replicating the study in another country in order to make a cross-cultural comparison and, finally, carrying out a case study with a group of pharmacies that received training in entrepreneurship and comparing the before and after.

Author Contributions: Conceptualization, S.R., C.S.M. and G.S.; methodology, S.R. and G.S.; software, G.S.; validation, C.S.M. and G.S.; formal analysis, G.S.; investigation, S.R.; resources, C.S.M.; data curation, G.S. and S.R.; writing — original draft preparation, S.R.; writing — review and editing, C.S.M. and G.S.; visualization, S.R.; supervision, C.S.M. and G.S.; project administration, C.S.M.; funding acquisition, C.S.M. All authors have read and agreed to the published version of the manuscript.

Funding: This work is supported by national funds, through FCT-Portuguese Foundation for Science and Technology under the project UIDB/04011/2020.

Institutional Review Board Statement: The study was conducted according to the guidelines of the Declaration of Helsinki and approved by the Institutional Review Board of Ethics Committee of the University of Trás-os-Montes and Alto Douro (protocol code 2019-11-19 approved in 19 November 2019).

Informed Consent Statement: Informed consent was obtained from all subjects involved in the study.

Acknowledgments: We gratefully acknowledge all the pharmacy professionals who, in the middle of the pandemic, donated their time to fill out the questionnaires.

Conflicts of Interest: The authors declare no conflict of interest.

\section{References}

1. Goode, J.-V.; Owen, J.; Page, A.; Gatewood, S. Community-Based Pharmacy Practice Innovation and the Role of the CommunityBased Pharmacist Practitioner in the United States. Pharmacy 2019, 7, 106. [CrossRef] [PubMed]

2. Policarpo, V.; Romano, S.; António, J.H.C.; Correia, T.S.; Costa, S. A new model for pharmacies? Insights from a quantitative study regarding the public's perceptions. BMC Health Serv. Res. 2019, 19, 186. [CrossRef]

3. Cavicchi, C.; Vagnoni, E. Sustainable Business Models in Hybrids: A Conceptual Framework for Community Pharmacies' Business Owners. Sustainability 2020, 12, 8125. [CrossRef]

4. Santuari, A. Legal and organisational innovation in the Italian pharmacy system: Commercial vs. public interest. Health Econ. Policy Law 2017, 12, 495-513. [CrossRef]

5. Mogul, A.; Laughlin, E.; Lynch, S. A Co-Curricular Activity to Introduce Pharmacy Students to the Concepts of Innovation and Entrepreneurship. Am. J. Pharm. Educ. 2020, 84, ajpe7805. [CrossRef] [PubMed]

6. Bogers, M.; Foss, N.J.; Lyngsie, J. The "human side" of open innovation: The role of employee diversity in firm-level openness. Res. Policy 2018, 47, 218-231. [CrossRef]

7. Scott, S.G.; Bruce, R.A. Determinants of Innovative Behavior: A Path Model of Individual Innovation in the Workplace. Acad. Manag. J. 1994, 37, 580-607. [CrossRef]

8. Calantone, R.J.; Cavusgil, S.T.; Zhao, Y. Learning orientation, firm innovation capability, and firm performance. Ind. Mark. Manag. 2002, 31, 515-524. [CrossRef]

9. Weng, R.-H.; Huang, C.-Y.; Huang, J.-A.; Wang, M.-H. The cross-level impact of patient safety climate on nursing innovation: A cross-sectional questionnaire survey. J. Clin. Nurs. 2012, 21, 2262-2274. [CrossRef]

10. Ferreira, J.; Coelho, A. Dynamic capabilities, innovation and branding capabilities and their impact on competitive advantage and SME's performance in Portugal: The moderating effects of entrepreneurial orientation. Int. J. Innov. Sci. 2020, 12, 255-286. [CrossRef]

11. de Jong, J.; Hartog, D.D. Measuring Innovative Work Behaviour. Creat. Innov. Manag. 2010, 19, 23-36. [CrossRef]

12. Genc, E.; Dayan, M.; Genc, O.F. The impact of SME internationalization on innovation: The mediating role of market and entrepreneurial orientation. Ind. Mark. Manag. 2019, 82, 253-264. [CrossRef] 
13. Allinson, C.W.; Chell, E.; Hayes, J. Intuition and entrepreneurial behaviour. Eur. J. Work. Organ. Psychol. 2000, 9, 31-43. [CrossRef]

14. Alnuaimi, M.A.; Alzoubi, H.M.; Alnazer, N.N. Analysing the appropriate cognitive styles and its effect on strategic innovation in Jordanian universities. Int. J. Bus. Excel. 2017, 13, 127. [CrossRef]

15. Mirjana, P.B.; Ana, A.; Marjana, M.-S. Examining determinants of entrepreneurial intentions in Slovenia: Applying the theory of planned behaviour and an innovative cognitive style. Econ. Res. Ekon. Istraživanja 2018, 31, 1453-1471. [CrossRef]

16. Allinson, C.W.; Hayes, J. The Cognitive Style Index: A Measure of Intuition-Analysis for Organizational Research. J. Manag. Stud. 1996, 33, 119-135. [CrossRef]

17. Bendall, R.C.A.; Galpin, A.; Marrow, L.P.; Cassidy, S. Cognitive Style: Time to Experiment. Front. Psychol. 2016, 7, 1786. [CrossRef] [PubMed]

18. Estelami, H.; Nejad, M.G. The impact of cognitive style, entrepreneurial attitudes and gender on competitive price responses. $J$. Prod. Brand Manag. 2017, 26, 759-770. [CrossRef]

19. Groves, K.; Vance, C.; Choi, D. Examining Entrepreneurial Cognition: An Occupational Analysis of Balanced Linear and Nonlinear Thinking and Entrepreneurship Success. J. Small Bus. Manag. 2011, 49, 438-466. [CrossRef]

20. Riding, R.J. On the Nature of Cognitive Style. Educ. Psychol. 1997, 17, 29-49. [CrossRef]

21. Lomberg, C.; Kollmann, T.; Stöckmann, C. Different Styles for Different Needs-The Effect of Cognitive Styles on Idea Generation. Creat. Innov. Manag. 2016, 26, 49-59. [CrossRef]

22. Antoncic, B.; Hisrich, R.D. Clarifying the intrapreneurship concept. J. Small Bus. Enterp. Dev. 2003, 10, 7-24. [CrossRef]

23. Gawke, J.C.; Gorgievski, M.J.; Bakker, A.B. Measuring intrapreneurship at the individual level: Development and validation of the Employee Intrapreneurship Scale (EIS). Eur. Manag. J. 2019, 37, 806-817. [CrossRef]

24. Neessen, P.C.M.; Caniëls, M.C.J.; Vos, B.; De Jong, J.P. The intrapreneurial employee: Toward an integrated model of intrapreneurship and research agenda. Int. Entrep. Manag. J. 2019, 15, 545-571. [CrossRef]

25. Shaikh, N.F.; Nili, M.; Dwibedi, N.; Madhavan, S.S. Initial Validation of an Instrument for Measuring Entrepreneurial and Intrapreneurial Intentions in Student Pharmacists. Am. J. Pharm. Educ. 2019, 84, ajpe7624. [CrossRef]

26. Popov, B.; Varga, S.; Jelić, D.; Dinić, B. Psychometric evaluation of the Serbian adaptation of the individual entrepreneurial orientation scale. Educ. Train. 2019, 61, 65-78. [CrossRef]

27. Kollmann, T.; Christofor, J.; Kuckertz, A. Explaining individual entrepreneurial orientation: Conceptualisation of a cross-cultural research framework. Int. J. Entrep. Small Bus. 2007, 4, 325-340. [CrossRef]

28. Gupta, V.K.; Niranjan, S.; Goktan, B.A.; Eriskon, J. Individual entrepreneurial orientation role in shaping reactions to new technologies. Int. Entrep. Manag. J. 2016, 12, 935-961. [CrossRef]

29. Zollo, L.; Rialti, R.; Tron, A.; Ciappei, C. Entrepreneurial passion, orientation and behavior: The moderating role of linear and nonlinear thinking styles. Manag. Decis. 2021, 59, 973-994. [CrossRef]

30. Covin, J.G.; Rigtering, J.C.; Hughes, M.; Kraus, S.; Cheng, C.-F.; Bouncken, R.B. Individual and team entrepreneurial orientation: Scale development and configurations for success. J. Bus. Res. 2020, 112, 1-12. [CrossRef]

31. Cadogan, C.A.; Hughes, C.M. On the frontline against COVID-19: Community pharmacists' contribution during a public health crisis. Res. Soc. Adm. Pharm. 2021, 17, 2032-2035. [CrossRef]

32. Armstrong, S.J.; Priola, V. Individual Differences in Cognitive Style and their Effects on Task and Social Orientations of SelfManaged Work Teams. Small Group Res. 2001, 32, 283-312. [CrossRef]

33. Hayes, J.; Allinson, C.W. Cognitive Style and its Relevance for Management Practice. Br. J. Manag. 1994, 5, 53-71. [CrossRef]

34. Healey, M.; Hodgkinson, G.P. Rethinking the philosophical and theoretical foundations of organizational neuroscience: A critical realist alternative. Hum. Relat. 2014, 67, 765-792. [CrossRef]

35. Semin, G.R.; Garrido, M.V. Socially Situated Cognition. In Theory and Explanation in Social Psychology; Grabowski, B., Bodenhausen, G.V., Eds.; Guilford Press: Nova York, NY, USA, 2015; pp. 283-304.

36. Fowler, W. Cognitive Differentiation and Developmental Learning. Adv. Child Dev. Behav. 1980, 15, 163-206. [CrossRef] [PubMed]

37. Hung, H.-C.; Tung, W.-K.; Chen, L.-J. Learning Result of Sistematic Innovation Course Under Different Cognitive Styles for Students. Int. J. Organ. Innov. 2019, 12, 365-374.

38. Koudstaal, M.; Sloof, R.; Van Praag, M. Entrepreneurs: Intuitive or contemplative decision-makers? Small Bus. Econ. 2018, 53, 901-920. [CrossRef]

39. Armstrong, S.J.; Cools, E.; Sadler-Smith, E. Role of Cognitive Styles in Business and Management: Reviewing 40 Years of Research. Int. J. Manag. Rev. 2012, 14, 238-262. [CrossRef]

40. Witkin, H.A.; Goodenough, D.R. Field Dependence Revisited. In Educational Testing Service Research Bulletin; ETS Research Bulletin Series; Wiley: Hoboken, NJ, USA, 1976. [CrossRef]

41. Fowler, W. Sequence and Styles in Cognitive Development. In The Structuring of Experience; Užgiris, I.C., Fredric, W., Eds.; Plenum Press: New York, NY, USA, 1977; pp. 265-295.

42. Bălǎu, G.; Faems, D.; Bij, H. Team experiential cognitive style and team performance: The moderating impact of workplace setting. Creat. Innov. Manag. 2019, 28, 343-354. [CrossRef]

43. Sternberg, R.J.; Grigorenko, E.L. Are cognitive styles still in style? Am. Psychol. 1997, 52, 700-712. [CrossRef]

44. Cools, E.; Broeck, H.V.D. Development and Validation of the Cognitive Style Indicator. J. Psychol. 2007, 141, 359-387. [CrossRef]

45. Evans, J.S.B.T.; Stanovich, K.E. Dual-Process Theories of Higher Cognition. Perspect. Psychol. Sci. 2013, 8, 223-241. [CrossRef] 
46. Randerson, K.; DeGeorge, J.M.; Fayolle, A. Entrepreneurial opportunities: How do cognitive styles and logics of action fit in? Int. J. Entrep. Small Bus. 2016, 27, 19. [CrossRef]

47. Sadler-Smith, E. The role of intuition in entrepreneurship and business venturing decisions. Eur. J. Work. Organ. Psychol. 2015, 25, 212-225. [CrossRef]

48. Baldacchino, L. Intuition in Entrepreneurial Cognition. In Contributions to Management Science; Caputo, A., Pellegrini, M.M., Eds.; Springer: Singapore, 2019; pp. 29-56.

49. Castellano, S.; Maalaoui, A.; Safraou, I.; Reymond, E. Linking intuition and entrepreneurial intention: A compara-tive study among French and US student entrepreneurs. Int. J. Entrep. Innov. Manag. 2014, 18, 23-44. [CrossRef]

50. Aggarwal, I.; Woolley, A.W. Team Creativity, Cognition, and Cognitive Style Diversity. Manag. Sci. 2019, 65, 1586-1599. [CrossRef]

51. Akinci, C.; Sadler-Smith, E. Assessing Individual Differences in Experiential (Intuitive) and Rational (Analytical) Cognitive Styles. Int. J. Sel. Assess. 2013, 21, 211-221. [CrossRef]

52. Adomako, S.; Danso, A.; Uddin, M.; Damoah, J.O. Entrepreneurs' optimism, cognitive style and persistence. Int. J. Entrep. Behav. Res. 2016, 22, 84-108. [CrossRef]

53. De Visser, M.; Faems, D. Exploration and exploitation within firms: The impact of CEOs' cognitive style on incremental and radical innovation performance. Creat. Innov. Manag. 2015, 24, 359-372. [CrossRef]

54. Naseer, S.; Khawaja, K.F.; Qazi, S.; Syed, F.; Shamim, F. How and when information proactiveness leads to operational firm performance in the banking sector of Pakistan? The roles of open innovation, creative cognitive style, and climate for innovation. Int. J. Inf. Manag. 2021, 56, 102260. [CrossRef]

55. Franić, S.; Drnovšek, M. The role of regulatory focus and cognitive style in business angels' evaluation of an investment opportunity. Ventur. Cap. 2019, 21, 353-377. [CrossRef]

56. Wang, D.; Hao, L.; Maguire, P.; Hu, Y. The effects of cognitive style and emotional trade-off difficulty on information processing in decision-making. Int. J. Psychol. 2016, 53, 468-476. [CrossRef] [PubMed]

57. Abubakar, A.M.; Elrehail, H.; Alatailat, M.A.; Elçi, A. Knowledge management, decision-making style and organizational performance. J. Innov. Knowl. 2019, 4, 104-114. [CrossRef]

58. Anderson, B.S.; Kreiser, P.M.; Kuratko, D.F.; Hornsby, J.S.; Eshima, Y. Reconceptualizing entrepreneurial orientation. Strat. Manag. J. 2015, 36, 1579-1596. [CrossRef]

59. Baker, W.E.; Sinkula, J.M. The Complementary Effects of Market Orientation and Entrepreneurial Orientation on Profitability in Small Businesses. J. Small Bus. Manag. 2009, 47, 443-464. [CrossRef]

60. Kraus, S.; Breier, M.; Jones, P.; Hughes, M. Individual entrepreneurial orientation and intrapreneurship in the public sector. Int. Entrep. Manag. J. 2019, 15, 1247-1268. [CrossRef]

61. Lumpkin, G.; Dess, G.G. Linking two dimensions of entrepreneurial orientation to firm performance: The moderating role of environment and industry life cycle. J. Bus. Ventur. 2001, 16, 429-451. [CrossRef]

62. Smith, B.; Jambulingam, T. Entrepreneurial orientation: Its importance and performance as a driver of customer orientation and company effectiveness among retail pharmacies. Int. J. Pharm. Health Mark. 2018, 12, 158-180. [CrossRef]

63. Lumpkin, G.T.; Dess, G.G. Clarifying the Entrepreneurial Orientation Construct and Linking It to Performance. Acad. Manag. Rev. 1996, 21, 135. [CrossRef]

64. Mintzberg, H. Strategy-Making in Three Modes. Calif. Manag. Rev. 1973, 16, 44-53. [CrossRef]

65. Miller, D. The Correlates of Entrepreneurship in Three Types of Firms. Manag. Sci. 1983, 29, 770-791. [CrossRef]

66. Covin, J.G.; Slevin, D.P. The influence of organization structure on the utility of an entrepreneurial top management style. J. Manag. Stud. 1988, 25, 217-234. [CrossRef]

67. Wales, W.; Gupta, V.K.; Mousa, F.-T. Empirical research on entrepreneurial orientation: An assessment and suggestions for future research. Int. Small Bus. J. Res. Entrep. 2011, 31, 357-383. [CrossRef]

68. Rauch, A.; Wiklund, J.; Lumpkin, G.T.; Frese, M. Entrepreneurial orientation and business performance: An as-sessment of past research and suggestions for the future. Entrep. Theory Pract. 2009, 33, 761-787. [CrossRef]

69. Bolton, D.L.; Lane, M.D. Individual entrepreneurial orientation: Development of a measurement instrument. Educ. Train 2012, 54, 219-233. [CrossRef]

70. Koe, W.-L. The relationship between Individual Entrepreneurial Orientation (IEO) and entrepreneurial intention. J. Glob. Entrep. Res. 2016, 6, 13. [CrossRef]

71. Santos, G.; Marques, C.S.; Ferreira, J.J. Passion and perseverance as two new dimensions of an Individual Entrepreneurial Orientation scale. J. Bus. Res. 2020, 112, 190-199. [CrossRef]

72. Cardon, M.S.; Wincent, J.; Singh, J.; Drnovsek, M. The Nature and Experience of Entrepreneurial Passion. Acad. Manag. Rev. 2009, 34, 511-532. [CrossRef]

73. Gerschewski, S.; Lindsay, V.J.; Rose, E. Advancing the entrepreneurial orientation construct: The role of passion and perseverance. Rev. Int. Bus. Strat. 2016, 26, 446-471. [CrossRef]

74. Van Gelderen, M. Perseverance strategies of enterprising individuals. Int. J. Entrep. Behav. Res. 2012, 18, 630-648. [CrossRef]

75. Cools, E.; Broeck, H.V. Searching the Heffalump: Using Traits and Cognitive Styles to Predict Entrepreneurial Orientation. In Vlerick Leuven Gent Management School, Vlerick Leuven Gent Management School Working Paper Series; Vlerick Leuven Gent Management School: Gent, Belgium, 2006; p. 42. 
76. Blanka, C. An individual-level perspective on intrapreneurship: A review and ways forward. Rev. Manag. Sci. 2019, 13, 919-961. [CrossRef]

77. Lenka, U.; Chawla, S. Higher educational institutes as learning organizations for employer branding. Ind. Commer. Train. 2015, 47, 265-276. [CrossRef]

78. Gawke, J.C.; Gorgievski, M.J.; Bakker, A.B. Personal costs and benefits of employee intrapreneurship: Disentangling the employee intrapreneurship, well-being, and job performance relationship. J. Occup. Health Psychol. 2018, 23, 508-519. [CrossRef]

79. Gawke, J.C.; Gorgievski, M.J.; Bakker, A.B. Employee intrapreneurship and work engagement: A latent change score approach. J. Vocat. Behav. 2017, 100, 88-100. [CrossRef]

80. Jong, J.P.J.; Parker, S.K.; Wennekers, S.; Wu, C. Corporate entrepreneurship at the individual level: Measurement and determinants. In EIM Research Reports, Netherlands; EIM: Amsterdam, The Netherlands, 2011. Available online: https://api.semanticscholar.org/ CorpusID:67848372 (accessed on 16 January 2020).

81. Antoncic, J.A.; Antonic, B. Employee satisfaction, intrapreneurship and firm growth: A model. Ind. Manag. Data Syst. 2011, 111, 589-607. [CrossRef]

82. Pandey, J.; Gupta, M.; Hassan, Y. Intrapreneurship to engage employees: Role of psychological capital. Manag. Decis. 2020, 59, 1525-1545. [CrossRef]

83. Razavi, S.H.; Ab Aziz, K. The dynamics between entrepreneurial orientation, transformational leadership, and intrapreneurial intention in Iranian R\&D sector. Int. J. Entrep. Behav. Res. 2017, 23, 769-792. [CrossRef]

84. Johannessen, J.; Olsen, B.; Lumpkin, G. Innovation as newness: What is new, how new, and new to whom? Eur. J. Innov. Manag. 2001, 4, 20-31. [CrossRef]

85. Taques, F.H.; López, M.G.; Basso, L.F.; Areal, N. Indicators used to measure service innovation and manufacturing innovation. J. Innov. Knowl. 2021, 6, 11-26. [CrossRef]

86. Bunce, D.; West, A.M. Self perceptions and perceptions of group climate as predictors of individual innovation at work. Appl. Psycol. Int. Rev. 1995, 44, 199-215. [CrossRef]

87. Drucker, P.F. The Practice of Management; Harper \& Row: New York, NY, USA, 1954.

88. Zahra, S.A. The Practice of Management: Reflections on Peter F. Drucker's landmark book. Acad. Manag. Perspect. 2003, 17, 16-23. [CrossRef]

89. Kessel, M.; Hannemann-Weber, H.; Kratzer, J. Innovative work behavior in healthcare: The benefit of operational guidelines in the treatment of rare diseases. Health Policy 2012, 105, 146-153. [CrossRef] [PubMed]

90. Lukes, M.; Stephan, U. Measuring employee innovation: A review of existing scales and the development of the innovative behavior and innovation support inventories across cultures. Int. J. Entrep. Behav. Res. 2017, 23, 136-158. [CrossRef]

91. Mirkov, S. Teamwork for innovation in pharmacy practice: From traditional to flexible teams. Drugs Ther. Perspect. 2018, 34, 274-280. [CrossRef]

92. Morales, V.J.G.; Matías-Reche, F.; Torres, N.E.H. Influence of transformational leadership on organizational innovation and performance depending on the level of organizational learning in the pharmaceutical sector. J. Organ. Chang. Manag. 2008, 21, 188-212. [CrossRef]

93. Weir, N.M.; Newham, R.; Dunlop, E.; Bennie, M. Factors influencing national implementation of innovations within community pharmacy: A systematic review applying the Consolidated Framework for Implementation Research. Implement. Sci. 2019, 14, 1-16. [CrossRef]

94. Liu, C.-H.S.; Lee, T. The multilevel effects of transformational leadership on entrepreneurial orientation and service innovation Int. J. Hosp. Manag. 2019, 82, 278-286. [CrossRef]

95. Alegre, J.; Chiva, R. Linking Entrepreneurial Orientation and Firm Performance: The Role of Organizational Learning Capability and Innovation Performance. J. Small Bus. Manag. 2013, 51, 491-507. [CrossRef]

96. Widya-Hasuti, A.; Mardani, A.; Streimikiene, D.; Sharifara, A.; Cavallaro, F. The Role of Process Innovation between Firm-Specific Capabilities and Sustainable Innovation in SMEs: Empirical Evidence from Indonesia. Sustainability 2018, 10, 2244. [CrossRef]

97. Hastuti, A.W.; Talib, N.B.A.; Wong, K.Y.; Mardani, A. The role of intrapreneurship for sustainable innovation through process innovation in small and medium-sized enterprises: A conceptual framework. Int. J. Econ. Financ. Issues 2016, 6, 83-91. Available online: https:/ / www.econjournals.com/index.php/ijefi/article/view/2615 (accessed on 17 November 2020).

98. Wan, W.; Liu, L.; Wang, X. How user-driven innovation and employee intrapreneurship promote platform enterprise performance. Manag. Decis. 2020, 58, 2705-2723. [CrossRef]

99. Carlucci, D.; Mura, M.; Schiuma, G. Fostering employees' innovative work behaviour in healthcare organisations. Int. J. Innov. Manag. 2019, 24. [CrossRef]

100. Podsakoff, P.M.; MacKenzie, S.B.; Lee, J.Y.; Podsakoff, N.P. Common method biases in behavioral research: A critical review of the literature and recommended remedies. J. Appl. Psychol. 2003, 88, 879-903. [CrossRef] [PubMed]

101. Chang, S.-J.; Van Witteloostuijn, A.; Eden, L. From the Editors: Common method variance in international business research. J. Int. Bus. Stud. 2010, 41, 178-184. [CrossRef]

102. Kock, N.; Lynn, G.S. Lateral collinearity and misleading results in variance-based SEM: An illustration and recommendations. $J$. Assoc. Inf. Syst. 2012, 13, 546-580. [CrossRef]

103. Chin, W.W. The partial least squares approach to structural equation modeling. Mod. Methods Bus. Res. 1998, 295, $295-336$. 
104. Chin, W.W. How to write up and report PLS analyses. In Handbook of Partial Least Squares: Concepts, Methods and Applications in Marketing and Related Fields; Vinzi, V.E., Chin, W.W., Henseler, J., Wang, H., Eds.; Springer: Berlin/Heidelberg, Germany, 2010; pp. 655-690.

105. Hair, J.F.; Hult, G.T.M.; Ringle, C.M.; Sarstedt, M. A Primer on Partial Least Squares Structural Equation Modeling (PLS-SEM); Sage: Thousand Oaks, CA, USA, 2017.

106. Henseler, J.; Ringle, C.M.; Sinkovics, R.R. The use of partial least squares path modeling in international marketing. In Advances in International Marketing; Sinkovics, R.R., Ghauri, P.N., Eds.; Emerald Group Publishing Limited: Bradford, UK, 2009; pp. 277-319. [CrossRef]

107. Agarwal, R.; Karahanna, E. Time Flies When You're Having Fun: Cognitive Absorption and Beliefs about Information Technology Usage. MIS Q. 2000, 24, 665. [CrossRef]

108. Becker, J.M.; Klein, K.; Wetzels, M. Hierarchical Latent Variable Models in PLS-SEM: Guidelines for Using Reflective-Formative Type Models. Long Range Plan. 2012, 45, 359-394. [CrossRef]

109. Ringle, C.M.; Sarstedt, M.; Straub, D.W. A critical look at the use of PLS-SEM in MIS Quarterly. MIS Q. 2012, 36, iii-xiv. [CrossRef]

110. Hair, J.F.; Risher, J.J.; Sarstedt, M.; Ringle, C.M. When to use and how to report the results of PLS-SEM. Eur. Bus. Rev. 2019, 31, 2-24. [CrossRef]

111. Diamantopoulos, A.; Sarstedt, M.; Fuchs, C.; Wilczynski, P.; Kaiser, S. Guidelines for choosing between multi-item and single-item scales for construct measurement: A predictive validity perspective. J. Acad. Mark. Sci. 2012, 40, 434-449. [CrossRef]

112. Dijkstra, T.K.; Henseler, J. Consistent Partial Least Squares Path Modeling. MIS Q. 2015, 39, 297-316. [CrossRef]

113. Fornell, C.; Larcker, D.F. Evaluating structural equation models with unobservable variables and measurement error. J. Mark. Res. 1981, 18, 39-50. [CrossRef]

114. Henseler, J.; Ringle, C.M.; Sarstedt, M. A new criterion for assessing discriminant validity in variance-based structural equation modeling. J. Acad. Mark. Sci. 2015, 43, 115-135. [CrossRef]

115. Voorhees, C.M.; Brady, M.K.; Calantone, R.J.; Ramirez, E. Discriminant validity testing in marketing: An analysis, causes for concern, and proposed remedies. J. Acad. Mark. Sci. 2016, 44, 119-134. [CrossRef]

116. Bagozzi, R.P.; Yi, Y. On the evaluation of structural equation models. J. Acad. Mark. Sci. 1988, 16, 74-94. [CrossRef]

117. Cohen, J. Statistical Power Analysis for the Behavioral Sciences, 2nd ed.; Lawrence Erlbaum Associat: Illsdale, NJ, USA, 1988.

118. Hair, J.F.; Ringle, C.M.; Sarstedt, M. PLS-SEM: Indeed a Silver Bullet. J. Mark. Theory Pract. 2011, 19, 139-152. [CrossRef]

119. Geisser, S. A predictive approach to the random effect model. Biometrika 1974, 61, 101-107. [CrossRef]

120. Stone, M. Cross-Validatory Choice and Assessment of Statistical Predictions. J. R. Stat. Soc. Ser. B Stat. Methodol. 1974, 36, 111-133. [CrossRef]

121. Kock, N. Common method bias in PLS-SEM: A full collinearity assessment approach. IJEC 2015, 11, 1-10. [CrossRef]

122. Nitzl, C. The use of partial least squares structural equation modelling (PLS-SEM) in management accounting re-search: Directions for future theory development. J. Account. Lit. 2016, 37, 19-35. [CrossRef]

123. Zhao, X.; Lynch, J.G., Jr.; Chen, Q. Reconsidering Baron and Kenny: Myths and Truths about Mediation Analysis. J. Consum. Res. 2010, 37, 197-206. [CrossRef]

124. Baldacchino, L.; Ucbasaran, D.; Cabantous, L.; Lockett, A. Entrepreneurship Research on Intuition: A Critical Analysis and Research Agenda. Int. J. Manag. Rev. 2015, 17, 212-231. [CrossRef]

125. Dutta, D.K.; Thornhill, S. Venture Cognitive Logics, Entrepreneurial Cognitive Style, and Growth Intentions: A Conceptual Model and an Exploratory Field Study. Entrep. Res. J. 2014, 4, 147-166. [CrossRef]

126. Laureiro-Martínez, D.; Brusoni, S. Cognitive flexibility and adaptive decision-making: Evidence from a laboratory study of expert decision makers. Strat. Manag. J. 2018, 39, 1031-1058. [CrossRef]

127. Mustafa, M.; Gavin, F.; Hughes, M. Contextual Determinants of Employee Entrepreneurial Behavior in Support of Corporate Entrepreneurship: A Systematic Review and Research Agenda. J. Enterprising Cult. 2018, 26, 285-326. [CrossRef]

128. Ferreira, F.A.F.; Jalali, M.S.; Bento, P.; Marques, C.S.E.; Ferreira, J.J.M. Enhancing individual entrepreneurial orientation measurement using a metacognitive decision making-based framework. Int. Entrep. Manag. J. 2017, 13, 327-346. [CrossRef]

129. Bouncken, R.B.; Plüschke, B.D.; Pesch, R.; Kraus, S. Entrepreneurial orientation in vertical alliances: Joint product innovation and learning from allies. Rev. Manag. Sci. 2016, 10, 381-409. [CrossRef]

130. Wiklund, J.; Shepherd, D. Entrepreneurial orientation and small business performance: A configurational approach. J. Bus. Ventur. 2005, 20, 71-91. [CrossRef]

131. Asiaei, K.; Barani, O.; Bontis, N.; Arabahmadi, M. How intrapreneurship intervenes in the intellectual capi-tal-performance relationship? J. Intellect. Cap. 2020, 1469-1930. [CrossRef]

132. Natividade, J.D.; Ferreira, F.A.; Zopounidis, C.; Pereira, L.F.; Çipi, A.; Ferreira, J.J. Developing a composite index for intrapreneurial orientation in small and medium-sized enterprises: A comprehensive dual methodology. J. Oper. Res. Soc. 2021, 72, 1674-1687. [CrossRef]

133. Wikström, P.-A. Sustainability and organizational activities-Three approaches. Sustain. Dev. 2010, 18, 99-107. [CrossRef] 